\title{
EUROPEAN CHRISTIAN CHURCHES AND THEIR LEVEL OF INFLUENCE*
}

\author{
S.A. Mudrov \\ Baranovichi State University, \\ Parkovaya St., 62, Baranovichi, 225404, Belarus \\ (e-mail: mudrov@tut.by)
}

\begin{abstract}
The article evaluates the level of influence of the Christian Churches in the European Union. In order to identify this influence, the author considers such variables as the degree of the religiosity of the state and the presence of Churches at the supranational (EU) level. Using the parameters of religiosity belief in God, belonging to a particular denomination, and the confidence in the Church - the author identifies areas of high, medium and low influence of the Churches in the EU. The area of high influence includes Cyprus, Greece, Malta, Romania, Italy, Croatia and Poland; the medium influence area includes Germany, Spain, Finland, Ireland, Slovenia, Portugal, Denmark, Sweden, Luxembourg, Slovakia, Bulgaria, Hungary, Lithuania and Austria; and the low influence area - Estonia, the Czech Republic, France, the UK, Belgium, Latvia and the Netherlands. Only countries with the homogenous Catholic or Orthodox population are inside the area of the high influence, while the countries with multi-confessional population are mainly in the area of low influence. This is partly due to the historical circumstances, but also to the rivalry between denominations, their ability to work together, and peculiarities of social doctrines. The author believes that all Christian denominations, with the exception of some Free Churches, show readiness to cooperate with the EU institutions on a variety of issues, which is confirmed by the growing number of religious representations in Brussels, where the Catholic Church has managed to establish the most influential and professional bodies, followed by the Orthodox and then by the mainstream Protestants. However, European institutions do not show the same degree of openness and eagerness to interact with the Christian Churches as the latter express about interacting with the EU.
\end{abstract}

Key words: European Union; European integration; Treaty of Lisbon; religion; religiosity; Christianity; Churches; level of influence

The Christian Churches play a unique role in the European integration. First, due to the appropriate contribution to the initial stages of the process. Second, they embrace the features of non-state actors and use similar methods to achieve their aims. Third, the Christian Churches contribute to the formation of both European and national identities. There is one more feature, which adds to the uniqueness of the Churches and at the same time allows to assess their possible degree of involvement in the integration or the European Union politics, - this is the Church-state regimes, i.e. a unique and distinct feature, peculiar to the Christian Churches only and in contrast to all other actors of the European integration. The article develops in detail the concept of Churches as specific participants of the European integration and, especially, assesses their level of influence in the European Union. A number of important factors are considered to achieve this aim: the Churches' organisational structures, their interest in the EU politics and their attitudes towards the EU determine the ecclesiastical level of influence. The de-

* S.A. Mudrov, 2016. 
gree to which a state is religious and the presence of the Churches at the supranational (EU) level are also relevant. Taking all this into account enables to estimate in detail how the Churches exercise their influence in various ways, and what level of influence is achieved by different denominations.

\section{HISTORICAL AND CONFESSIONAL TRAJECTORIES}

The formation of the Church-state systems has been a long and complicated process, not without its own conflicts and disputes. The modern models of the Church-state relations mostly developed in the XXth century since earlier "church and state institutions were closely intertwined" [11. P. 252]. In fact, in most countries of what is now the EU the monarchs generally dominated the Church and even assumed the right to appoint bishops and, furthermore, to interfere in the doctrinal issues [11. P. 253 - 255]. Thus, the relations between the Church and the state were largely unequal; this inequality was disadvantageous for the Churches. There is also a theory that the confessional structure had an impact on the Church-state relations. For instance, H. Knippenberg believes that the Church-state relations differ substantially between the Western and Eastern Christianity, "and this divide can be expected to have direct implications and consequences not only for political conflicts in the European states, but also for the religious landscapes involved" [6. P. 255]. His view is similar to that of John Madeley: "the pattern of church-state relations in society $\mathrm{X}$ can, in part at least, be explained by the fact that it is a mono-confessional Orthodox or Catholic or Lutheran society; alternatively, in the case of society $\mathrm{Y}$, that it is a multi-confessional society with a particular range and balance of confessions represented. To make sense of these patterns, two factors must be examined in each case: the character of the different confessional traditions, particularly as this relates to church-state relations, and how strongly they are represented relative to other traditions [9. P. 34].

If we accept J. Madeley's concept of the mono-confessional blocs and multi-confessional belts, then the confessional distribution in the EU will be as follows: (a) Austria, Belgium, Croatia, France, Poland, Ireland, Lithuania, Luxembourg, Portugal, Spain, the Czech Republic, Slovakia, Malta, Slovenia and Italy belong to the Catholic bloc; (b) Romania, Bulgaria, Greece and Cyprus belong to the Orthodox bloc; (c) Denmark, Sweden and Finland belong to the Lutheran bloc. The remaining six EU countries (Germany, the United Kingdom, the Netherlands, Hungary, Latvia and Estonia) cannot be regarded as mono-confessional states, although there are only a few religious minorities in some of them. However, in some of these states the substantial confessional changes are observed: for example, in Estonia traditionally regarded as a Lutheran country more people now identify themselves as Orthodox than as Lutherans according to the last census data [14].

\section{RELIGIOSITY AS A FACTOR OF THE CHURCHES' INFLUENCE}

No mainstream Christian Church totally abstains from participation in the European integration process. Only sectarian Protestants, who are extremely hostile towards the EU, try to build a wall of separation between themselves and the European institutions. However, this is an exception, not a rule. In the framework of this participation, the Churches can interact with national governments on the EU issues. This interaction 
can be more intense and successful for those Churches, which are more influential and highly rated within their own countries. Their level of influence is also determined by the level of religiosity and historical circumstances of their countries. In fact, the Churches can exercise more influence in the countries, in which they have more adherents (among the electorate of politicians) and contributed positively to some historical developments (for example, the Catholic Church's support for the "Solidarność" movement in Poland).

Indeed, as was noted by J. Haynes, "the more secularized a society, the less likely religious organisations will be able to play a politically significant role" [5. P. 5]. The Churches are able to influence the EU developments through the authorities of member states. However, this depends on the ability of Churches to play "a politically significant role" in their countries. In order to assess the Churches' possible significance and their ability to influence the national political settings (which depends on the ability to exercise influence at the European level), we need to identify the level of religiosity in the EU member states through the objective parameters. These include the level of belief in God and people's self-identification with a particular denominational group. In addition, the level of general trust to particular Churches helps to assess their potential influence. The latest data on the level of belief in God in Europe is available for 2010. The questions asked by the Eurobarometer distinguish the pure belief in God (presumably more of a Christian character) and a vague belief in some sort of spirit or life force. The data is available for all EU countries (see Table 1).

Table 1

The level of belief in God (\%) [12. P. 204]

\begin{tabular}{|l|c|c|}
\hline \multicolumn{1}{|c|}{ Country } & You believe there is a God & $\begin{array}{c}\text { You believe there is some } \\
\text { sort of spirit or life force }\end{array}$ \\
\hline Belgium & 37 & 31 \\
\hline Bulgaria & 36 & 43 \\
\hline Cyprus & 88 & 8 \\
\hline Czech Republic & 16 & 25 \\
\hline Germany & 44 & 47 \\
\hline Denmark & 28 & 50 \\
\hline Estonia & 18 & 48 \\
\hline Latvia & 38 & 39 \\
\hline Netherlands & 28 & 14 \\
\hline Poland & 79 & 15 \\
\hline Portugal & 70 & 7 \\
\hline Romania & 92 & 45 \\
\hline Sweden & 18 & 20 \\
\hline Spain & 59 & 42 \\
\hline Finland & 33 & 27 \\
\hline France & 27 & 33 \\
\hline United Kingdom & 37 & 16 \\
\hline Greece & 79 & 34 \\
\hline Hungary & 45 & 20 \\
\hline Ireland & 70 & 4 \\
\hline Malta & 94 & 20 \\
\hline Italy & 74 & 38 \\
\hline Austria & 44 & 37 \\
\hline Lithuania & 47 & 22 \\
\hline Luxembourg & 46 & 36 \\
\hline Slovenia & 32 & 23 \\
\hline Slovakia & 63 & \\
\hline Croatia & 69 & 22 \\
\hline & & \\
\hline
\end{tabular}


It is worth noting that the number of non-believers does not exceed $50 \%$ in any EU country being highest in France (40\%), the Czech Republic (37\%), the Netherlands (30\%), Estonia (29\%), Germany and Belgium (27\% each) [12. P. 204]. The latest data on belonging to a particular denomination is available for 2012. This figure shows if people are willing to proclaim their religiosity and demonstrate their association with an organised religion. The question was "Do you consider yourself to be...?", and respondents were able to express their religious affiliation. Most of them chose a Christian denomination: Catholic, Orthodox or Protestant; some chose "other Christian'. This data, which is the sum of those who articulated their belonging to particular denomination, is presented in Table 2 .

Table 2

Belonging to a Christian denomination (\%) [13. P. T98]

\begin{tabular}{|l|c|}
\hline \multicolumn{1}{|c|}{ Country } & $\begin{array}{c}\text { Total percentage of those } \\
\text { belonging to a denomination }\end{array}$ \\
\hline Belgium & 65 \\
\hline Bulgaria & 85 \\
\hline Cyprus & 99 \\
\hline Czech Republic & 34 \\
\hline Germany & 65 \\
\hline Denmark & 71 \\
\hline Estonia & 45 \\
\hline Latvia & 69 \\
\hline Netherlands & 44 \\
\hline Poland & 92 \\
\hline Portugal & 93 \\
\hline Romania & 98 \\
\hline Sweden & 52 \\
\hline Spain & 71 \\
\hline Finland & 82 \\
\hline France & 58 \\
\hline United Kingdom & 58 \\
\hline Greece & 97 \\
\hline Hungary & 71 \\
\hline Ireland & 92 \\
\hline Malta & 96 \\
\hline Italy & 92 \\
\hline Austria & 86 \\
\hline Lithuania & 90 \\
\hline Luxembourg & 75 \\
\hline Slovenia & 68 \\
\hline Slovakia & 78 \\
\hline & \\
\hline & 98 \\
\hline
\end{tabular}

Thus, in $27 \mathrm{EU}$ countries for which the Eurobarometer data is available (all member states except Croatia) only in three (the Czech Republic, Estonia, and the Netherlands) the majority of population do not belong to any denomination or religion.

The third factor, which needs to be taken into account, is the level of confidence in the Church. Here the most recent data is available for 2008. The data of the European Values Study show that the level of confidence in the Church remains high in many EU countries. The number of people who say they have "a great deal" or "quite a lot" of confidence in the Church constitutes the majority in Croatia (53.2\%), Cyprus (69.5\%), Italy (64.2\%), Portugal (73.5\%), Greece (54.3\%), Malta (79.8\%), Denmark (60.6\%), Ireland (54.6\%), Latvia (60.2\%), Lithuania (70.6\%), Poland (62.7\%), Slovakia (59.3\%) 
and Romania (85.3\%). Even in other EU member states, where the level of confidence in the Church is not substantially high, no particularly high level of mistrust was recorded. The very negative assessment ("none at all") exceeded 30\% only in two cases: the Czech Republic - 44\% and Spain - 33.9\%, and closely approached 30\% in Germany (28.1\%) and Belgium (27\%) [4].

If we combine three parameters analysed above, we can refer to the existence of different areas of Churches' influence in the EU. The area of high influence includes Cyprus, Greece, Malta, Romania, Italy, Croatia and Poland; of medium influence Germany, Spain, Finland, Ireland, Slovenia, Portugal, Denmark, Sweden, Luxembourg, Slovakia, Bulgaria, Hungary, Lithuania and Austria; and of low influence - Estonia, the Czech Republic, France, the United Kingdom, Belgium, Latvia and the Netherlands. Only Orthodox and Catholic countries with highly homogenous religious populations constitute the Churches' areas of high influence, while the countries from the multiconfessional belts are mainly in the area of low influence. This is partly due to their historical circumstances, but also to the rivalry between denominations, their ability (or inability) to work together and the peculiarities of social doctrines (since the liberalisation of social doctrines and practices often alienates believers and does not attract new ones). These three areas enable us to identify countries where the higher participation of the Churches in the national politics (and their corresponding influence at the supranational level) is expected, and areas where participation is expected to be lower. However, to get a full picture of the situation, we need to look at the Churches at the supranational level.

\section{CHURCHES AT THE SUPRANATIONAL LEVEL}

The presence of the Churches at the supranational level is a crucial indicator for defining how actively and successfully the Churches can monitor the EU policy-making. It is of particular importance in their attempts to influence the decision-making process. The work of representations in Brussels is also a reflection of the Churches' interest in EU developments and their desire to participate in the European integration. First, it is important to underline that only the Roman Catholic Church has established its presence in the EU at the diplomatic level in two forms: the Embassy of the Holy See to the EU, and the mission of the Sovereign Military Order of Malta. Of course, the Papal Nuncio (appointed first in the capacity of a Nuncio for the European Community in 1970) takes it as a natural task to defend, using diplomatic means, Vatican's interests at the European level. The Sovereign Order of Malta's circumstances are not as favorable as for the Holy See: the representation of the Order is recognized as a diplomatic entity by the European Commission, but not by the EU member states. However, no other religious representation is regarded as a diplomatic mission; none could even acquire this status.

The Transparency Register website of the European Commission lists 50 organizations in the Section V "Organizations representing churches and religious communities". However, not all religious organisations have chosen to register in the Section. Some (for example, Christian Solidarity Worldwide, Eurodiaconia, Christian Aid and other) chose to register in the Section III "Non-governmental organizations", and a small number of organizations did not register at all. The religious representations are mainly Chris- 
tian [15]. Certainly, not all organizations have the functioning staff, a clear agenda, and an ability to monitor developments in the EU, particularly with attempts to influence its decision-making process. We can classify these representations along denominational lines. L. Leustean also suggests making a distinction along the following functional parameters: the official representation of Churches, inter-Church or convictional organizations or networks, religious orders, and single-issue organizations [8. P. 307].

The Catholic organizations working on a wide range of issues include the Commission of the Bishops' Conferences of the European Union (COMECE), Jesuit European Social Centre, and Caritas Europa. Single-issue organisations are normally concerned about immigration and refugees (one can mention here the International Catholic Migration Commission and the Jesuit Refugee Service Europe). The Orthodox representations tend to concentrate on broader issues, and include representations of the Churches of Greece, Romania, Cyprus, the Moscow Patriarchate, and the Liaison Office of the Orthodox Church (Ecumenical Patriarchate). Finally, Protestants are represented by a number of different organizations, including the Evangelical Church in Germany (EKD) office, European Evangelical Alliance, Christian Action, Research and Education (CARE for Europe), representations of the Anglican Church and of Free Churches. The ecumenical organizations are best represented by the Conference of European Churches (CEC).

\section{CHURCHES' WORK IN BRUSSELS}

The analysis of practical cooperation between the Churches and the EU institutions is important to see in more detail how the work of representations in Brussels is organized. Practical cooperation between Christian organisations and European institutions usually takes form of consultations and meetings. L. Leustean distinguishes two main types of meetings: working groups (when experts from both sides focus together on specific issues), and " "photo opportunities between the highest levels of political and religious leadership in Europe" (when Presidents of the European Council, Parliament, and Commission are present, as well as Church leaders and leaders of other religions) [8. P. 309-310]. Although "photo opportunity" meetings are the most visible to the press and general public, they seem to be mainly ceremonial with few practical consequences. There have been twelve such meetings since 2005 (Table 3).

These meetings do not give much opportunity either for substantial interventions or for discussions. It is hardly possible to have a deep and profound discussion in a meeting which only takes place once a year, lasts for two hours, and is attended by more than 20 participants. In contrast to these photo-op meetings, the working groups are more practical and provide more opportunities for influence, especially if the Church experts are good professionals in the field. However, there are no formal rules to oversee the special involvement of Christian organizations in the EU's policy-making. The Church experts work alongside experts from secular organisations, and there is unlikely to be any preference towards the former from European institutions. Moreover, in certain cases the Church affiliation can even lead to some uneasiness, if partners have strong antiChurch views or oppose any sort of religious involvement in policy, even in the form of expertise not related to a religious agenda. 
High-Level Meetings Between Religious and Political Leaders in the EU [2]

\begin{tabular}{|c|c|c|}
\hline Date & Theme & Confessions present \\
\hline July 2005 & Rejection of terrorism and ongoing EU integration & $\begin{array}{l}\text { Catholic, Protestant, Orthodox, } \\
\text { Judaism and Islam }\end{array}$ \\
\hline May 2006 & Fundamental rights and mutual respect & $\begin{array}{l}\text { Catholic, Protestant, Orthodox, } \\
\text { Judaism, Islam and Buddhism }\end{array}$ \\
\hline May 2007 & Building a Europe based on human dignity & $\begin{array}{l}\text { Catholic, Protestant, Orthodox, } \\
\text { Judaism and Islam }\end{array}$ \\
\hline May 2008 & Climate change and reconciliation & $\begin{array}{l}\text { Catholic, Protestant, Orthodox, } \\
\text { Judaism and Islam }\end{array}$ \\
\hline May 2009 & $\begin{array}{l}\text { Economic and financial crisis: ethical contributions } \\
\text { for European and global economic governance }\end{array}$ & $\begin{array}{l}\text { Catholic, Protestant, Orthodox, } \\
\text { Judaism and Islam }\end{array}$ \\
\hline July 2010 & Combating poverty and social exclusion & $\begin{array}{l}\text { Catholic, Protestant, Orthodox, Juda- } \\
\text { ism, Islam, Hinduism and Sikhism }\end{array}$ \\
\hline May 2011 & $\begin{array}{l}\text { A partnership for democracy and shared prosper- } \\
\text { ity: a common willingness to promote democratic } \\
\text { rights and liberties }\end{array}$ & $\begin{array}{l}\text { Catholic, Protestant, Orthodox, } \\
\text { Judaism, Islam and Buddhism }\end{array}$ \\
\hline July 2012 & $\begin{array}{l}\text { Intergenerational solidarity: setting the parame- } \\
\text { ters for tomorrow's society in Europe }\end{array}$ & $\begin{array}{l}\text { Catholic, Protestant, Orthodox, Juda- } \\
\text { ism, Islam, Hinduism and Baha'ism }\end{array}$ \\
\hline May 2013 & $\begin{array}{l}\text { Putting citizens at the heart of the European pro- } \\
\text { ject in times of change }\end{array}$ & $\begin{array}{l}\text { Catholic, Protestant, Orthodox, } \\
\text { Judaism, Islam and Hinduism }\end{array}$ \\
\hline June 2014 & The future of the European Union & $\begin{array}{l}\text { Catholic, Protestant, Orthodox, } \\
\text { Judaism, Islam, Hinduism, Sikhism } \\
\text { and Mormonism }\end{array}$ \\
\hline June 2015 & Living together and disagreeing well & $\begin{array}{l}\text { Catholic, Protestant, Orthodox, } \\
\text { Judaism, Islam, Hinduism, Buddhism } \\
\text { and Mormonism }\end{array}$ \\
\hline $\begin{array}{l}\text { November } \\
2016\end{array}$ & Migration, integration and European values & $\begin{array}{l}\text { Catholic, Protestant, Orthodox, Juda- } \\
\text { ism, Islam, Hinduism and Mormonism }\end{array}$ \\
\hline
\end{tabular}

In principle, after the Treaty of Lisbon was entered into force in 2009, it could have been expected that the Churches would have better opportunities for the influence at the supranational (European) level. As L. Leustean noted, "the latest Lisbon Treaty gives religious communities a more significant position and institutes a consultation framework with the European institutions" [7. P. 175]. Indeed, Article 17 (3) of the Treaty on the Functioning of the European Union envisages "open, transparent and regular dialogue" with the Churches (as well as with philosophical and non-confessional organizations). In April 2010, COMECE and CSC [Church and Society Commission] CEC articulated their "General considerations" on the implementation of this provision of the Treaty of Lisbon. They emphasized, in particular, that the Churches' dialogue partners should include the Council, Commission, and Parliament, but also "other EU institutions and bodies" [1. P. 3], and that opportunities for dialogue should be given to both minority and majority Churches.

Explaining the characteristics of such dialogue, COMECE and CSC CEC noted the following: the openness means that the EU institutions should be willing "to work with citizens towards the goal of 'involvement in the lawmaking and governance' of the EU" [1. P. 4]. One more feature of this openness is that no policy field within the EU's legislative and governmental competence should be excluded from this dialogue. It should also be "frank" and can focus, inter alia, on the promotion of universal values, as mentioned in the Preamble of the Treaty on European Union, on "the respect of human 
dignity of every human being, reconciliation and intercultural understanding, as well as on the realization of the principles of subsidiarity and solidarity in EU policy" [1. P. 4]. Transparency is explained as a good opportunity to allow the interested public to know the Churches' perspectives on EU issues and an opportunity for the EU institutions to disseminate their views to a wider audience. The provision for a regular dialogue is particularly developed, with the Christian organizations emphasizing that regular dialogue "goes above and beyond sporadic ad-hoc meetings between representatives of Churches and EU institutions" [1. P. 5]. The Churches stressed that the future dialogue framework should improve and enhance the existing one at all levels: working contacts, consultations, dialogue seminars, and high-level meetings. In fact, those high-level and most visible meetings need "common content preparation prior to the events as well as any subsequent follow-up" [1. P. 5]. Also COMECE and CEC pointed out that they would welcome participating in the hearings organised by the European Parliament. All this confirms the Churches' readiness to closely cooperate with EU institutions.

In contrast, the European Commission's official website does not provide such substantial and inclusive definitions of the characteristics of this dialogue as elaborated by the Christian Churches. To the European Union the openness means that the "dialogue partners can be churches, religious associations or communities, as well as philosophical and non-confessional organizations that are recognized or registered as such at national level and adhere to European values". Transparent dialogue means that the European Commission, on a dedicated website, "conveys to the public all relevant information about the activities within the dialogue." Finally, regular dialogue means that "the European Commission maintains a regular dialogue with interlocutors at various levels in the form of written exchanges, meetings, or specific events" without specification of how regularly [3].

This rather reserved tone on the part of the European Commission can be considered a confirmation of R. McCrea's claim that the EU, while being not strictly secular, can in practice impose some limitations on the return of religion to the political arena $[10$. P. 13]. It appears that the European institutions do not show the same degree of openness and eagerness to interact with the Christian Churches that the Churches express about interacting with the EU. Certainly, it was the Churches' achievement that in the text of the Lisbon Treaty the provisions for their dialogue with the EU were separated from the dialogue with the civil society. However, it was partially watered down by the inclusion of "philosophical and non-confessional organizations" in this dialogue. Moreover, the Churches initially requested "structured" dialogue, but this word did not appear in the Article 17. Consequently, the Article 17, if fully applied, simply means dialogue with almost everyone, without any specific obligations from the European Union. In fact, putting this Article into practice still remains an issue of concern, since it is difficult to organize the dialogue with hundreds of different denominations. Therefore, it appears that the Churches will have more chances to increase their influence if the cooperation at the policy level will become more intensive - then it is likely that the Churches will be more heard in the Brussels' corridors of power. 


\section{$* * *$}

This article develops the concept of the Churches as unique participants of the European integration and assesses their level of influence in the EU. To evaluate the Churches' influence, various important parameters were taken into account. First, the existing Church-state relations in the EU member states. Second, the practical cooperation between the Churches and the EU institutions. All Christian denominations (except some Free Churches) show readiness to cooperate with the EU institutions on a variety of issues. This is clearly confirmed by the growing number of religious representations in Brussels, where the Catholic Church managed to establish the most influential and professional bodies, followed by the Orthodox and then by the mainstream Protestants. In addition, the Churches work together through ecumenical organizations such as the Conference of European Churches. The Roman Catholic Church exerts a higher degree of influence and involvement at the supranational level, while at the national level this depends on the circumstances of the particular country. The variations can be tremendous even between countries within the same confessional group.

Taking into account the parameters of religiosity (the belief in God, belonging to a particular denomination and the confidence in the Church) we identified the areas of the high, medium and low influence of Churches in the EU. The area of high influence includes Cyprus, Greece, Malta, Romania, Italy, Croatia and Poland; of medium influence - Germany, Spain, Finland, Ireland, Slovenia, Portugal, Denmark, Sweden, Luxembourg, Slovakia, Bulgaria, Hungary, Lithuania and Austria; and of low influence - Estonia, the Czech Republic, France, the United Kingdom, Belgium, Latvia and the Netherlands. Thus, only countries with the homogenous Catholic or Orthodox population are inside the area of high influence. The Catholic countries are located in all three groups, which confirms that the level of influence of the Church at the national level depends not only on the denominational parameter.

\section{REFERENCES}

[1] COMECE and CSC CEC, 2010. Article 17 of the Treaty on the Functioning of the European Union. General considerations on the implementation of the dialogue: Paragraph 3. Available from: http://csc.ceceurope.org/fileadmin/filer/csc/European_Integration/20100427_COMECECSC_Proposal_on_Article_17_TFEU.pdf.

[2] European Commission, 2017. Dialogue with Churches, Religious Associations or Communities and Philosophical and Non-Confessional Organizations. Available from: http://ec.europa.eu/ newsroom/just/item-detail.cfm?item_id $=50189$.

[3] European Commission: Guidelines on the implementation of the Article 17 TFEU. Available from: http://www.eurel.info/IMG/pdf/guidelines-implementation-art-17.pdf.

[4] European Values Study: Integrated Dataset, 2008. Variable v205: How much confidence in: Church. Available from: http://zacat.gesis.org/webview/index.jsp?object=http://zacat.gesis.org/ obj/fCatalog/Catalog5.

[5] Haynes J. (Ed.) Religion and Politics in Europe, the Middle East and North Africa. Routledge, 2010.

[6] Knippenberg H. The political geography of religion: Historical state-church relations in Europe and recent challenges. GeoJournal. 2006;67.

[7] Leustean L. What is the European Union? Religion between neofunctionalism and intergovernmentalism. International Journal for the Study of the Christian Church. 2009;9(3). 
[8] Leustean L. Representing religion in the European Union. A typology of actors. Politics, Religion and Ideology. 2011;12(3).

[9] Madeley J. A framework for the comparative analysis of church-state relations in Europe. West European Politics. 2003;26(1).

[10] McCrea R. Religion and the Public Order of the European Union. Oxford Scholarship Online, 2011.

[11] Riedel S. Models of church-state relations in European democracies. Journal of Religion in Europe. 2008;1(3).

[12] Special Eurobarometer 341, 2010. Biotechnology. Available from: http://ec.europa.eu/public opinion/archives/ebs/ebs_341_en.pdf.

[13] Special Eurobarometer 393, 2012. Discrimination in the EU. Available from: http://ec.europa.eu/ public_opinion/archives/ebs/ebs_393_en.pdf.

[14] Statistics Estonia, 2013: Over a quarter of the population are affiliated with a particular religion. Available from: http://www.stat.ee/65352.

[15] Transparency Register. Available from: http://ec.europa.eu/transparencyregister/public/ homePage.do?redir=false\&locale $=$ en.

DOI: $10.22363 / 2313-2272-2017-17-1-63-72$

\title{
ЕВРОПЕЙСКИЕ ХРИСТИАНСКИЕ ЦЕРКВИ И УРОВЕНЬ ИХ ВЛИЯНИЯ*
}

\author{
С.А. Мудров \\ Барановичский государственный университет, \\ ул. Парковая, 62, Барановичи, 225404, Беларусь \\ (e-mail:mudrov@tut.by)
}

В статье оценивается уровень влияния христианских церквей в Европейском Союзе. Для определения уровня этого влияния учитываются такие параметры, как степень религиозности в конкретной стране и присутствие церквей на наднациональном уровне (Европейского Союза). С учетом параметров религиозности - веры в Бога, принадлежности к конкретной конфессии и доверия церкви определяются территории высокого, среднего и низкого влияния церквей в Евросоюзе. Зона высокого влияния включает в себя Кипр, Грецию, Мальту, Румынию, Италию, Хорватию и Польшу, зона среднего влияния - Германию, Испанию, Финляндию, Ирландию, Словению, Португалию, Данию, Швецию, Люксембург, Словакию, Болгарию, Венгрию, Литву и Австрию, а зона низкого влияния - Эстонию, Чехию, Францию, Соединенное Королевство, Бельгию, Латвию и Нидерланды. Только государства с однородным православным или католическим населением вошли в зону высокого влияния, в то время как страны с многоконфессиональным составом населения находятся, как правило, в зоне низкого влияния. Это частично связано с историческими обстоятельствами, а также с соперничеством между конфессиями, с их способностью (или неспособностью) к совместной работе и с особенностями их социальных доктрин. Автор отмечает, что все христианские конфессии (исключая отдельных неопротестантов) демонстрируют готовность сотрудничать с институтами Евросоюза. Данный факт подтверждается растущим количеством религиозных представительств в Брюсселе, где наиболее влиятельной является Католическая церковь, за которой следует Православная церковь и традиционные протестанты. Однако европейские институты не проявляют той же открытости и желания взаимодействовать с христианскими церквями, что очевидны со стороны церквей в отношении Евросоюза.

Ключевые слова: Европейский Союз; европейская интеграция; Лиссабонский договор; религия; религиозность; христианство; церкви; уровень влияния

* Мудров С.А., 2016. 